\title{
Genetic and cytogenetic variation of African root-rats Tachyoryctes splendens (Mammalia: Rodentia) from Ethiopia
}

\author{
Leonid A. Lavrenchenko*, Sewnet Mengistu, Nina Sh. Bulatova, \\ Afework Bekele, Sergei G. Potapov, Rena S. Nadjafova \& Gurja Belay
}

\begin{abstract}
Genetic and cytogenetic variation of African root-rats Tachyoryctes splendens sensu lato from Ethiopia was assessed on 23 complete cytochrome $b$ gene sequences (1140 bp) and chromosomal sets from eight individuals. Results of this study suggest that the real diversity of Ethiopian Tachyoryctes splendens s.l. has been underestimated due to its apparent cryptic diversification. The molecular genetic analysis reveals genetic subdivision including at least four allopatric and deeply divergent mitochondrial lineages, restricted to the Simien Mountains and the Northern, Southern and Eastern parts of the Ethiopian Plateau. Three of them possess unique karyotypes while chromosomal characteristics of the Eastern lineage remain unknown. These lineages may represent distinct species, however additional analyses of molecular, chromosomal and morphological data should be conducted to confirm our preliminary results and provide a real basis for species delimitation within Ethiopian Tachyoryctes splendens s.l.
\end{abstract}

KEY WORDS: African root-rats, Tachyoryctes splendens, Ethiopia, phylogeography, cytochrome $b$, mitochondrial DNA, chromosomes.

Leonid A. Lavrenchenko [llavrenchenko@gmail.com], A.N. Severtsov Institute of Ecology and Evolution RAS, Leninskii pr. 33, Moscow 119071, Russia; Sewnet Mengistu [sewnetmengistutsige@yahoo.com], Department of Biology, Haramaya University, Dire Dawa 138, Ethiopia; Nina Sh. Bulatova [bulatova.nina@gmail.com], A.N. Severtsov Institute of Ecology and Evolution RAS, Leninskii pr. 33, Moscow 119071, Russia; Afework Bekele [afeworkbekele@hotmail.com], Addis Ababa University,Department of Zoological Sciences, Addis Ababa 1176, Ethiopia; Sergei G. Potapov [psg2110@rambler.ru], A.N. Severtsov Institute of Ecology and Evolution RAS, Leninskii pr. 33, Moscow 119071, Russia; Rena S. Nadjafova [renan8@yahoo.com], A.N. Severtsov Institute of Ecology and Evolution RAS, Leninskii pr. 33, Moscow 119071, Russia; Gurja Belay [gurja_belay@yahoo.com], Addis Ababa University, Department of Zoological Sciences, Addis Ababa 1176, Ethiopia

\section{Генетическая и цитогенетическая изменчивость восточноафриканских кротовых крыс Tachyoryctes splendens (Mammalia: Rodentia) из Эфиопии}

\section{Л.А. Лавренченко, Севнет Менгисту, Н.Ш. Булатова, Афеворк Бекеле, С.Г. Потапов, Р.С. Наджафова, Гурджа Белай}

РЕЗЮМЕ. В результате предварительного исследования молекулярно-генетической и цитогенетической изменчивости африканских кротовых крыс Tachyoryctes splendens sensu lato из Эфиопии, проведен анализ 23 полных последовательностей гена цитохрома $b$ (1140 пн) и хромосомных наборов восьми экземпляров. Результаты данного исследования показали, что реальное генетическое разнообразие эфиопских Tachyoryctes splendens s.1. ранее было недооценено из-за очевидной криптической диверсификации в пределах этого надвидового комплекса. Молекулярно-генетический анализ выявил наличие четырех глубоко дивергировавших митохондриальных линий, аллопатрически распространенных, соответственно, в Симиенских горах, а также в северной, южной и восточной частях Эфиопского нагорья. Три из них обладают уникальными кариотипами, хромосомные характеристики Восточной линии остаются неизвестными. Эти четыре диагностируемые линии могут представлять различные виды. Для подтверждения наших предварительных результатов и определения видовых границ в пределах Tachyoryctes splendens s.1. необходимы дополнительные анализы молекулярных, хромосомных и морфологических данных.

КЛЮЧЕВЫЕ СЛОВА: африканские кротовые крысы, Tachyoryctes splendens, Эфиопия, филогеография, цитохром $b$, митохондриальная ДНК, хромосомы. 
$33^{\circ} \mathrm{E} 34^{\circ} \mathrm{E} 35^{\circ} \mathrm{E} 36^{\circ} \mathrm{E} 37^{\circ} \mathrm{E} 38^{\circ} \mathrm{E} 39^{\circ} \mathrm{E} 40^{\circ} \mathrm{E} 41^{\circ} \mathrm{E} 42^{\circ} \mathrm{E} 43^{\circ} \mathrm{E} 44^{\circ} \mathrm{E} \quad 45^{\circ} \mathrm{E} 46^{\circ} \mathrm{E} 47^{\circ} \mathrm{E}$

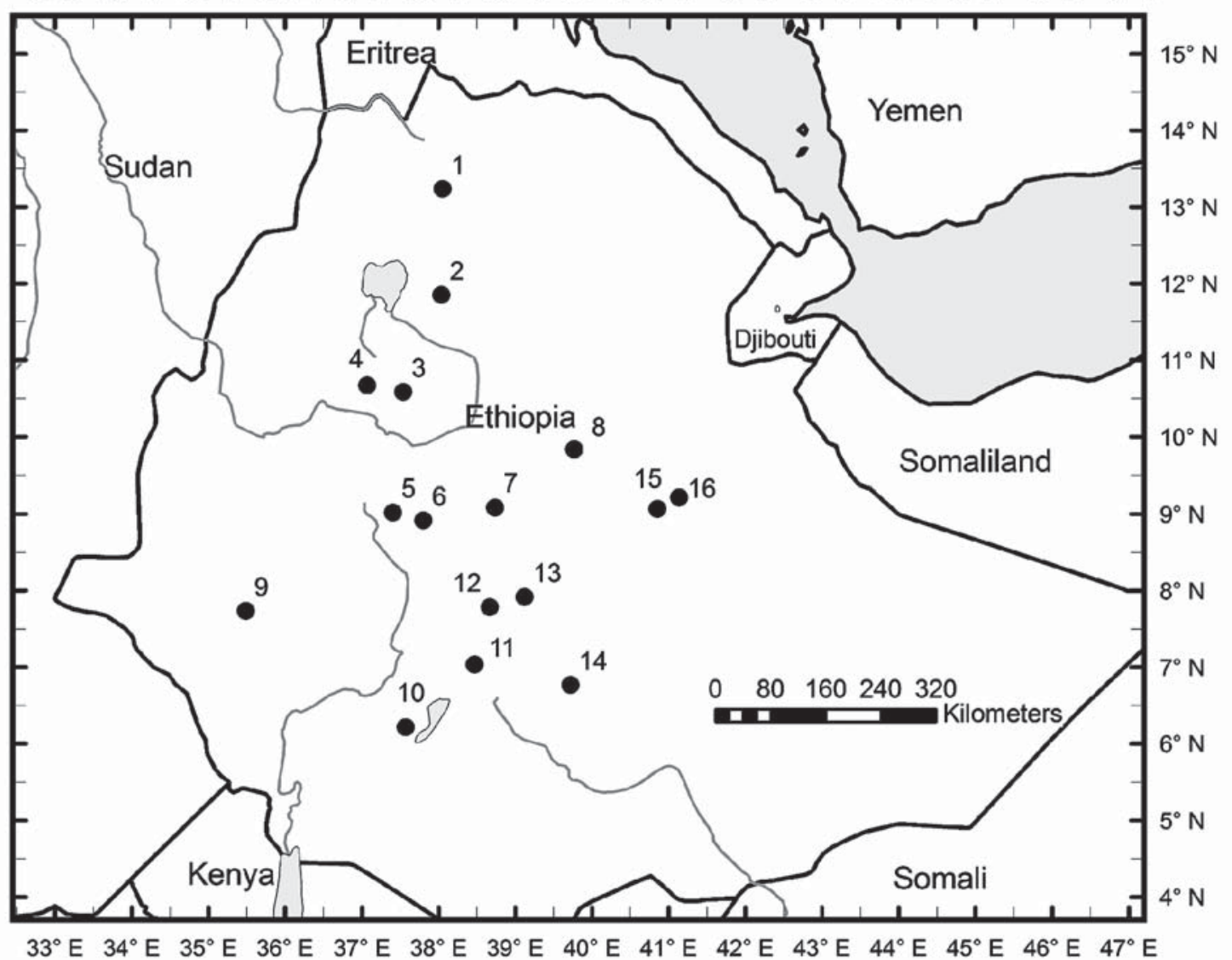

Figure 1. Map of sampling localities for Ethiopian Tachyoryctes splendens s.l. For the designations of the localities see the text.

\section{Introduction}

The root-rats of the African endemic genus Tachyoryctes Rüppell, 1835 are solitary subterranean rodents, living underground in semi-permanent burrow-systems. They are exclusively herbivores feeding on a wide range of vegetation including grasses, herbs and underground storage organs (Jarvis, 2013). The genus is distributed in East Africa and eastern parts of Central Africa. It ranges from the eastern Democratic Republic of the Congo into Rwanda and Burundi, northern Tanzania, Kenya, Uganda and throughout much of Ethiopia to northwestern Somalia at altitudes ranging from 1200 $\mathrm{m}$ to over $4000 \mathrm{~m}$ (Yalden et al., 1976; Musser \& Carleton, 2005; Jarvis, 2013). The Northern (Ethiopian) part of the range of this genus is separated from the rest by dry lowland uninhabitable for Tachyoryctes. Their isolated position attributes particular interest to Ethiopian root-rats, which presumably evolved in this area under isolation. The taxonomy of the Ethiopian Tachyoryctes has a turbulent history. Seven taxa were described from Ethiopia and northwestern Somalia, based on the variation in pelage coloration and external and cranial measurements: T. splendens (Rüppell, 1835); T. s. somalicus Osgood, 1910; T. s. omensis Neumann and Rümmler, 1928; T. pontifex Neumann and Rümmler, 1928; T. cheesmani Thomas, 1928; T. s. canicaudus Osgood, 1936; and T. c. gallarum Osgood, 1936. Craniometric analyses based on rather limited samples have revealed significant differences between Ethiopian populations attributed to $T$. splendens s.str. and $T$. cheesmani (Afework Bekele, 1986; Sewnet Mengistu \& Afework Bekele, 2003). Nevertheless, until recently all these taxa were lumped under T. splendens (Musser \& Carleton, 2005). Furthermore, large T. macrocephalus (Rüppell, 1842) is known only from a restricted range in the Bale Mountains (South-Eastern Ethiopia) (Yalden et al., 1976). This specialised Afroalpine species is morphologically well differentiated from any other representative of the genus. Eleven additional species were recognized from the remaining part of the distribution range of the genus outside Ethiopia: $T$. ankoliae Thomas, 1909; T. annectens (Thomas, 1891); T. audax Thomas, 1910; T. daemon Thomas, 1909; T. ibeanus Thomas, 1900; T. naivashae Thomas, 1909; T. 
rex Heller, 1910; T. ruandae Lönnberg and Gyldenstolpe, 1925; T. ruddi Thomas, 1909; T. spalacinus Thomas, 1909; and T. storeyi Thomas, 1909. An extended study of cranial morphology based on geometric morphometric analyses confirmed only the specific status of T. macrocephalus and suggested the lumping of all other taxa into a single species, T. splendens (Beolchini \& Corti, 2004). In particular, only slight differences were observed between $T$. cheesmani and $T$. splendens s.str. Therefore, only two Tachyoryctes species have been recognised in Ethiopia: T. splendens, widespread throughout most of East Africa, and $T$. macrocephalus, endemic to the Bale Mountains. Cytogenetic analyses revealed complex karyotypic differences between these two taxa studied in the Bale Mountains, regarding diploid number and chromosome morphology (fundamental, or chromosome arm number): $2 \mathrm{n}=48, \mathrm{FNa}=65-86$ for $T$. splendens, and $2 \mathrm{n}=50, \mathrm{FNa}=$ 62 for T. macrocephalus (Aniskin et al., 1997). It was uncertain whether FN differences reported for T. splendens from a few samples in- and outside Ethiopia had any taxonomic value or reflected specific adaptations of populations to a limited ecological niche under isolation conditions. To further test the hypotheses extended analyses based on chromosomal studies and DNA sequencing are needed. In this paper we examine, for the first time, the cytogenetic and mitochondrial DNA ( $\mathrm{mtD}$ NA) variation of representatives of $T$. splendens s.l. from Ethiopia.

\section{Material and methods}

The specimens examined were collected during trapping sessions in the course of the Joint EthiopianRussian Biological Expedition (JERBE) between 2005 and 2011. All voucher specimens are housed in the Natural History Museum of the Addis Ababa University, Ethiopia, and the Zoological Museum of the Moscow State University (ZMMU), Russia. Tachyoryctes splendens s.l. were collected at the following localities in Ethiopia (Fig. 1): (1) Simien Mountains National Park, Sankaber area $\left(13^{\circ} 14^{\prime} \mathrm{N} 38^{\circ} 03^{\prime} \mathrm{E}, 3250 \mathrm{~m}\right.$ a.s.l. $)$ 2 specimens, Chennek area $\left(13^{\circ} 15^{\prime} \mathrm{N} 38^{\circ} 13^{\prime} \mathrm{E}, 3800 \mathrm{~m}\right.$ a.s.1.) - 2 specimens; (2) Debre-Tabor $\left(11^{\circ} 51^{\prime} \mathrm{N}\right.$ $38^{\circ} 02^{\prime} \mathrm{E}, 2645 \mathrm{~m}$ a.s.1.) - 10 specimens; (3) Dembecha $\left(10^{\circ} 35^{\prime} \mathrm{N} 37^{\circ} 32^{\prime} \mathrm{E}, 2258 \mathrm{~m}\right.$ a.s.l. $)-8$ specimens; (4) Bure $\left(10^{\circ} 40^{\prime} \mathrm{N} 37^{\circ} 04^{\prime} \mathrm{E}, 2060 \mathrm{~m}\right.$ a.s.l. $)-10$ specimens; (5) Gedo $\left(09^{\circ} 01^{\prime} \mathrm{N} 37^{\circ} 24^{\prime} \mathrm{E}, 2058 \mathrm{~m}\right.$ a.s.1.) - 10 specimens; (6) Ambo $\left(08^{\circ} 55^{\prime} \mathrm{N} 37^{\circ} 48^{\prime} \mathrm{E}, 2300 \mathrm{~m}\right.$ a.s.l.) - 12 specimens; (7) Addis Ababa, Mt. Entoto $\left(09^{\circ} 05^{\prime} \mathrm{N} 38^{\circ} 44^{\prime} \mathrm{E}, 2982 \mathrm{~m}\right.$ a.s.1.) - 10 specimens; (8) Debre Sina $\left(09^{\circ} 50^{\prime} \mathrm{N} 39^{\circ} 44^{\prime}-39^{\circ} 46^{\prime} \mathrm{E}, 2570-3240 \mathrm{~m}\right.$ a.s.l.) - 20 specimens; (9) Masha $\left(07^{\circ} 44^{\prime} \mathrm{N} 35^{\circ} 29^{\prime} \mathrm{E}\right.$, 2250 m a.s.1.) - 8 specimens; (10) Chencha, Doko Mesho $\left(06^{\circ} 13^{\prime} \mathrm{N} 37^{\circ} 34^{\prime} \mathrm{E}, 2550 \mathrm{~m}\right.$ a.s.l. $)-12$ specimens; (11) Hawassa $\left(07^{\circ} 02^{\prime} \mathrm{N} 38^{\circ} 28^{\prime} \mathrm{E}, 1704 \mathrm{~m}\right.$ a.s.1.) - 10 specimens; (12) Adami Tullu $\left(07^{\circ} 47^{\prime} \mathrm{N} 38^{\circ} 40^{\prime} \mathrm{E}\right.$, 1654 m a.s.l.) - 12 specimens; (13) Asela, Chilalo Mt. $\left(07^{\circ} 55^{\prime} \mathrm{N} 39^{\circ} 07^{\prime} \mathrm{E}, 2525 \mathrm{~m}\right.$ a.s.1.) - 10 specimens; (14)
Bale Mountains National Park, Rira $\left(06^{\circ} 46^{\prime} \mathrm{N} 39^{\circ} 43^{\prime} \mathrm{E}\right.$, 2940 m a.s.1.) - 10 specimens; (15) Asbe Teferi (09 ${ }^{\circ}$ $04^{\prime} \mathrm{N} 40^{\circ} 51^{\prime} \mathrm{E}, 1880 \mathrm{~m}$ a.s.1.) - 10 specimens; (16) Hirna, Chercher Mts. $\left(09^{\circ} 13^{\prime} \mathrm{N} 41^{\circ} 08^{\prime} \mathrm{E}, 2400 \mathrm{~m}\right.$ a.s.1.) - 10 specimens.

We sequenced a total of 23 entire $(1140 \mathrm{bp})$ sequences of the mitochondrial gene cytochrome $b$. DNA was extracted from $96 \%$ alcohol preserved liver, kidney and muscle tissue by the standard phenol-chloroform method (Mathew, 1984). Complete cytochrome $b$ gene was amplified by PCR with the combination of the forward L14727-SP (5'-GACAGGAAAAATCATCGTTG-3') (Fink et al., 2004) and reverse H15915-SP (5'TTCATTACTGGTTTACAAGAC-3') (Fink et al., 2004) primers.

Template DNA was amplified by PCR in $25 \mu \mathrm{L}$ reaction volume containing the following: $1 \mathrm{X}$ reaction buffer, $10 \mathrm{mM}\left(\mathrm{NH}_{4}\right)_{2} \mathrm{SO}_{4}, 0.1 \%$ TWEEN 20, $2 \mathrm{mM}$ $\mathrm{MgCl}_{2}, 1 \mathrm{mM}$ of each dNTP, $0.1 \mathrm{mM}$ of each primer, 1 unit of Taq polymerase and 25-100 ng of template DNA. PCRs were performed under the following temperature profile: hot start at $94^{\circ} \mathrm{C}$ for $3 \mathrm{~min}, 35$ cycles of denaturation at $94^{\circ} \mathrm{C}$ for $30 \mathrm{~s}$, annealing at $50^{\circ} \mathrm{C}$ for 30 s, elongation at $72^{\circ} \mathrm{C}$ for $1 \mathrm{~min}$, and a final elongation at $72^{\circ} \mathrm{C}$ for $10 \mathrm{~min}$. Sequencing was performed on an ABI PRISM 310 DNA automatic analyser (Applied Biosystems, Forster City, CA, USA) using the same primers mentioned above and BigDye Terminators chemistry (Applied Biosystems). The sequences were checked for quality and aligned by eye. To avoid erroneous inclusion of Numts (nuclear sequences of mitochondrial origin) in the data sets, the codons of the complete cytochrome $b$ gene were translated into aminoacids to check for non-functional mutations. The sequences were submitted to the GenBank under accession numbers KM523600-KM523622.

We also used sequence data on relevant rodents from GenBank: Myospalax psilurus Milne-Edwards, 1874 (AF326271), Eospalax fontanierii Milne-Edwards, 1867 (AF326266), E. rothschildi Thomas, 1911 (AF326268) and Rhizomys sinensis Gray, 1831 (AF326274) (Zhou et al., 2004). These four Spalacidae taxa were selected as outgroups. We also included $c y t b$ sequence data on the only available non-Ethiopian representative of Tachyoryctes (AF160602) from Kenya (precise geographic locality unknown) (Jansa et al., 1999).

Phylogenetic relationships among entire sequences of the cytochrome $b$ gene were assessed using neighbour joining (NJ), maximum parsimony (MP) and maximum likelihood (ML) criteria implemented in PAUP* version 4.0b10 (Swofford, 2000), complemented with PAUPUP, version 1.0.3.1 (Calendini \& Martin, 2005). The NJ tree was reconstructed using the uncorrected $p$ distance. Unweighted MP analysis was performed using heuristic search starting with stepwise addition trees and employing tree bisection-reconnection branchswapping algorithm. ModelTest, version 3.04 (Posada \& Crandall, 1998) was employed for the choice of the 
best model of sequence evolution for the ML analyses, using the corrected Akaike information criterion (AICc) value. The supported substitution model was Hasegawa-Kishino-Yano 1985 (HKY $+\mathrm{G}+\mathrm{I}$, alpha=1.543, pin=0.511). Maximum likelihood was conducted using the heuristic search option and the parameters obtained from ModelTest. Clade stability of the NJ-MP and ML trees was assessed by bootstrapping with 1000 and 500 replicates, respectively. Genetic divergence between and within clades were computed as uncorrected $p$ distances with the software Mega version 3.1 (Kumar et al., 2004).

The chromosomal analysis was performed on $\mathrm{Ta}$ chyoryctes splendens s.l. from localities 1, 8 and 12 . Somatic metaphases of individuals were prepared from bone marrow by the usual air-drying technique according to Ford \& Hamerton (1956). Slide preparations were stained with $4 \%$ Giemsa in phosphate buffer with $\mathrm{pH}=7.0$ for routine karyotyping and C-stained for heterochromatin location according to Sumner (1972).

\section{Results}

\section{Analysis of mtDNA}

The complete cytochrome $b$ gene sequences among ingroup 23 haplotypes show 307 variable sites of which 240 are informative under parsimony. Analysis of the nucleotide composition within the ingroup revealed a deficiency in guanine (mean cytochrome $b: A=0.254$, $C=0.290, G=0.127, T=0.329$ ), which was typical of the cytochrome $b$ of rodents (Jaarola et al., 2004), as well as of mammals in general (Irwin et al., 1991). Mean pairwise transition/transversion ratio for cytochrome $b$ was 4.15 (as estimated by ML using the HKY substitution model with gamma distribution and alpha estimated from the data).

Phylogenetic trees constructed by use of the three main methods (NJ, MP, and ML) had very similar topology (Fig. 2). Uncorrected $p$-distances between distinct haplotypes are given in Tab. 1 . The phylogenetic analyses of complete cytochrome $b$ gene sequences retrieved three highly divergent lineages: Southern, Northern and Eastern. The results suggest the basal position of the Eastern lineage within the ingroup (bootstrap support $(\mathrm{BI})=54$ to $87 \%)$. The mean levels of the genetic divergence ( $p$-distance) between major phylogroups based on complete cytochrome $b$ gene sequencing are: Eastern-Northern - $11.82 \pm 0.87 \%$ of nucleotide substitutions, Eastern-Southern $-11.27 \pm 0.91 \%$, and Northern-Southern $-9.62 \pm 0.58 \%$. Besides the distinctness of clades, the relatively high distance values suggest that the clades may represent species and/or even species-groups.

The Southern phylogroup appeared to be a sister group to the single available specimen from Kenya $(\mathrm{BI}=59$ to $81 \%)$. Average $p$-distance between the Kenyan specimen and representatives of the Southern lineage was $9.03 \pm 0.71 \%$. The Southern phylogroup was further subdivided into three distinct subclades ((1) samples from south-eastern mountains (loc. 13, 14), (2) locality 7, (3) resting southern samples (loc. 10, 11, 12)) supported in NJ, MP and ML-analyses by sufficiently high bootstrap indices ( $\mathrm{BI}=96$ to $100 \%)$. The mean levels of the genetic divergence ( $p$-distance) between these three distinct subclades are: $1-2-6.11 \pm$ $0.73 \%, 1-3-5.97 \pm 0.69 \%, 2-3-6.45 \pm 0.64 \%$. According to the results of NJ, MP and ML-analyses, within the Northern phylogroup the most basal lineage was represented by the haplotype from the Simien Mountains (loc. 1) $(\mathrm{BI}=62-76 \%)$. Average $p$-distance between the Simien specimen and other representatives of the Northern lineage is $8.70 \pm 0.62 \%$. The rest of the Northern phylogroup was further subdivided into four distinct subclades ((1) northern localities 2 and 4, (2) locality 3 , (3) locality 8, (4) samples from central (loc. $5,6)$ and western (loc. 9) parts of the country). Three subclades were supported in NJ, MP and ML-analyses by sufficiently high bootstrap indices $(\mathrm{BI}=88$ to $100 \%)$, whereas one (loc. 2, 4) obtained only poor bootstrap support $(\mathrm{BI}=50$ to $73 \%)$. The level of genetic divergence ( $p$-distance) among these four subclades was in the range $6.02-8.61 \%$ (mean $7.13 \%$ ). The mean levels of the genetic differentiation ( $p$-distance) within major phylogroups based on complete cytochrome $b$ gene sequences are: Northern - $6.68 \pm 0.44 \%$, Southern $4.03 \pm 0.40 \%$, and Eastern - $1.65 \pm 0.40 \%$.

\section{Cytogenetic analysis}

Cytogenetic analyses detected two different 48-chromosome complements and a 50-chromosome variant new for Ethiopian T. splendens s.l. (Tab. 2). The karyotypes of specimens from localities 12 and 8 , both having $2 n=48$, resemble structurally the two formerly known karyotypes with minimal (3 pairs) and maximal (5 pairs) numbers of autosomal metacentrics, or, correspondingly, the 3MA and 5MA karyotypes (Fig. 3). They all have both large metacentric sex chromosomes, $\mathrm{X}$ and $\mathrm{Y}$, with a characteristic $\mathrm{C}$-banding pattern. The $\mathrm{Y}$ is entirely heterochromatic and looks dense even in routine stained preparations, and there is a large portion

Figure 2. Neighbour-joining (NJ) tree illustrating the phylogenetic relationships among the complete cytochrome $b$ gene haplotypes in the selected 23 specimens of the Ethiopian common root-rat (Tachyoryctes splendens). The tree is based on the uncorrected $p$-distances. The values of bootstrap index ( $>50 \%)$ are shown by the upper figures for NJ analysis, and by lower figures (slash-separated), for maximum parsimony (MP) and maximum likelihood (ML) analyses, respectively. Myospalax psilurus, Eospalax fontanierii, E. rothschildi and Rhizomys sinensis are used as outgroups. Collection localities are given before each Ethiopian specimen name with numbers that refer to those used in text and Fig. 1. 


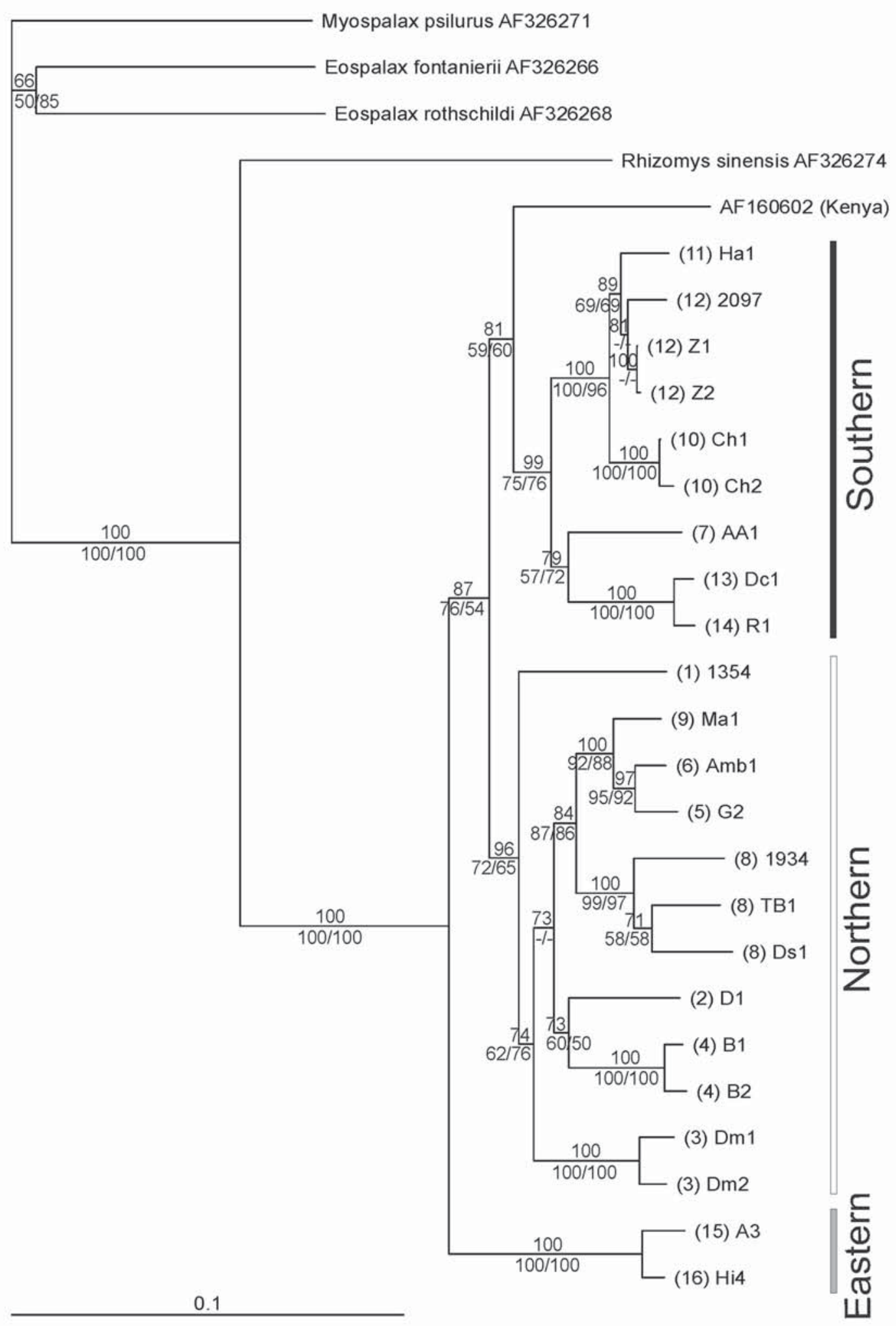


114 L.A. Lavrenchenko, S. Mengistu, N.Sh. Bulatova, A. Bekele, S.G. Potapov, R.S. Nadjafova, G. Belay

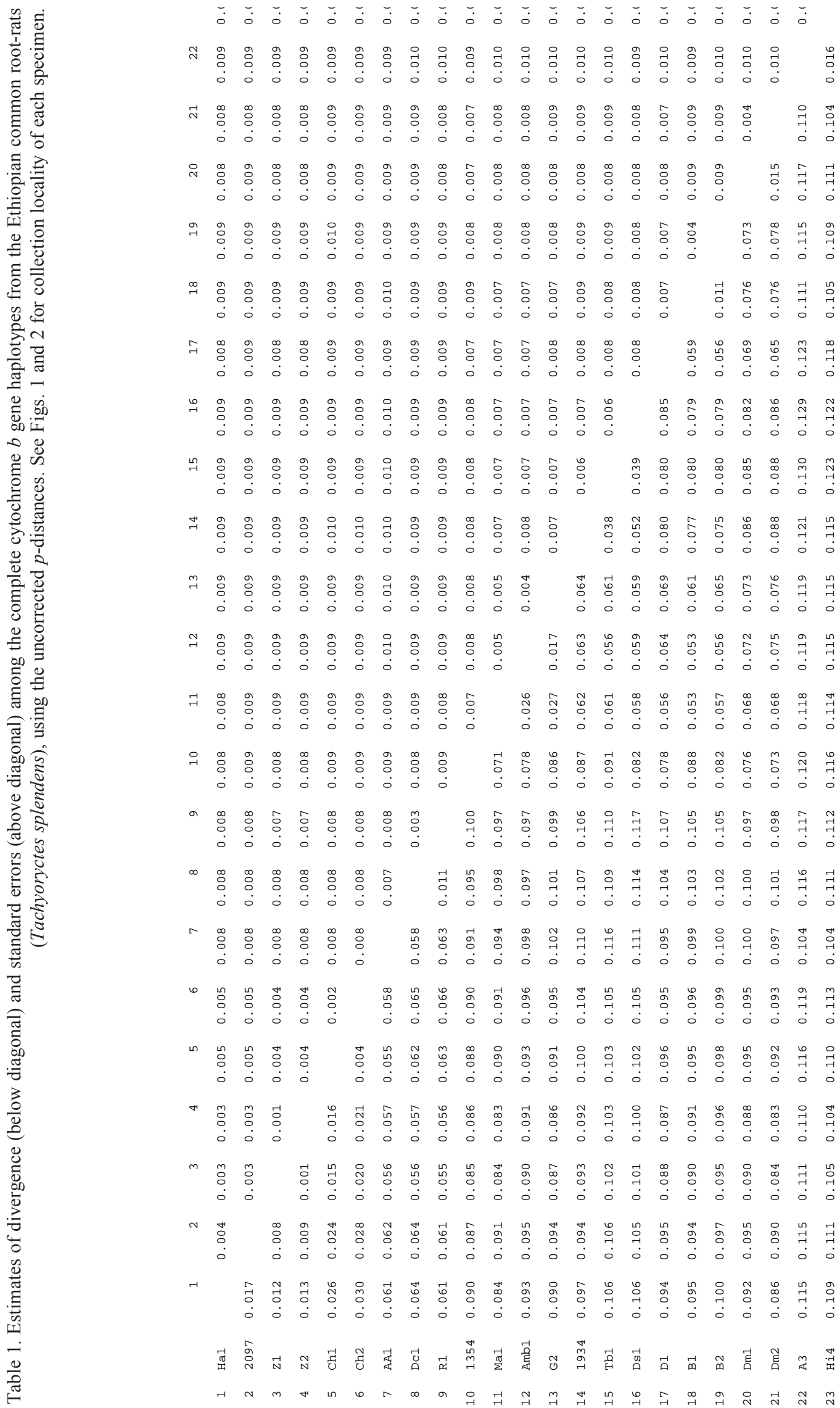


Table 2. Karyotypic data on Tachyoryctes collected from Ethiopia.

\begin{tabular}{|c|c|c|c|c|c|c|}
\hline Species & Location & $\begin{array}{c}\text { Number/ } \\
\text { Sex }\end{array}$ & $2 n$ & $\begin{array}{c}\text { DMA } \\
\text { (n) }\end{array}$ & $\mathbf{F N * *}$ & Reference \\
\hline T. macrocephalus & Bale Mts. & 3 3우 & 50 & 2 & 54 & Aniskin et al., 1997 \\
\hline T. splendens* & Bale Mts. & $20^{7} \sigma^{7}, 7+0$ & 48 & 3 & 54 & Aniskin et al., 1997 \\
\hline T. splendens* & $\begin{array}{l}\text { Koka Lake (Rift } \\
\text { Valley) }\end{array}$ & $2 \sigma^{7} \sigma^{x}, 2+q$ & 48 & 3 & 54 & $\begin{array}{l}\text { Baskevich et al., } \\
1993\end{array}$ \\
\hline T. cf. splendens* & Vanzaye & 19 & 48 & 5 & 58 & $\begin{array}{l}\text { Bulatova \& } \\
\text { Lavrenchenko, } 2005\end{array}$ \\
\hline T. splendens s.l. & Debre-Sina & $20^{7} 0^{7}$ & 48 & 5 & 58 & This study \\
\hline T. splendens s.l. & Adami-Tulu & $20^{7} 0^{x}$ & 48 & 3 & 54 & This study \\
\hline T. splendens $\mathrm{s} .1$. & $\begin{array}{l}\text { Simien Mts. } \\
\text { (Sankaber) }\end{array}$ & $10^{7}, 1+$ & 50 & 4 & 58 & This study \\
\hline T. splendens s.l. & $\begin{array}{l}\text { Simien Mts. } \\
\text { (Chennek) }\end{array}$ & 290 & 50 & 4 & 58 & This study \\
\hline
\end{tabular}

* As named in corresponding publications. DMA(n) - haploid number of diagnostic metacentrics, which only were regarded as biarmed elements against the rest "all-acrocentric" content in simplified FN** counts.

of C-heterochromatin in the long arm of the X chromosome not well distinct from its euchromatic part. Among autosomes, 3MA and 5MA diagnostic pairs look Cnegative.

C-banding pattern in the remaining autosomes is, however, different. In the 3MA karyotype from locality 12, C-blocks are stained in pericentromeric area of many, if not all the acrocentric chromosomes (Fig. 3A), as in T. splendens from the Bale Mountains or near the north-eastern shore of Koka Lake (Tab. 2) where some of the largest elements looked subtelocentric due to an increased amount of heterochromatic material in a short arm. By contrast, in the 5MA karyogram (loc. 8) Cstaining is restricted to short arms of four subacrocentric pairs (Fig. 3B).

The new karyotype with $2 n=50$ and four small metacentric pairs was detected in all four specimens obtained from two sites investigated in the Simien Mountains (loc. 1). It is structured similar to the above mentioned karyotypes and comprises large bi-armed sex chromosomes, four pairs of small metacentrics and 20 pairs of acro- or subacrocentrics. In the absence of Cstaining, it may be extrapolated, however, that short arms of larger subacrocentrics should be heterochromatic, as in the case of 5MA karyotype. The Y-chromosome looks compact and very likely should be C-positive as well (Fig. 3C).

Our results suggest a corrected count of chromosome number in heterochromatically variable karyotypes. It is worth to note that in former descriptions the elements with C-positive short arms were treated usually as subtelocentrics, and their proportion influenced the FN counts which were reported in a wide range from 62-65 to 86 due to the authors' views (Baskevich et al., 1993; Aniskin et al., 1997). One can see, however, that variation in $\mathrm{C}$-negative small metacentrics and subtelocentrics or subacrocentrics (in our current terminology) with heterochromatic additional short arm should be essentially independent (Fig. 3). To exclude the uncertain variety of heterochromatin, we compare FN counts only for "true", i.e. euchromatic metacentrics against originally one-armed groups, which comprised acrocentrics together with subacrocentrics or subtelocentrics. In view of this, the three karyotypes are to be presented in the following figures in our data: $2 \mathrm{n}=48, \mathrm{FN}=56, \mathrm{FNA}=52$ for $3 \mathrm{MA}$ karyotype; $2 \mathrm{n}=48$, $\mathrm{FN}=62, \mathrm{FNA}=58$ for $5 \mathrm{MA}$ karyotype; $2 \mathrm{n}=50, \mathrm{FN}=62$, $\mathrm{FNA}=58$ for $4 \mathrm{MA}$ karyotype (Tab. 2). It follows from such a consideration that correspondence of $2 \mathrm{~N} / \mathrm{FN}$ figures might show the participation of a Robertsonianlike rearrangement only between karyotypes 3MA/4MA, but remains unsolved in the case of 5MA karyotype relations with each of those two karyotypes.

Regarding the FN comparisons, one more correction has to be made. A minute bi-armed pair was reported as a peculiarity of the of 5MA karyotype in its first presentation for Vanzaye (Bulatova \& Lavrenchenko, 2005). The quality of field chromosome preparations from a new site, Debre-Sina (loc. 8), was not good enough to recognise the arms in members of the smallest pair looking like the tiny chromatin bodies (Fig. 3B, Tab. 2). The same is true for the 4MA karyotype, though some heteromorphisms between two minimal chromosomes can be registered in metaphase spreads on the same preparation. It is likely that unsteady chromosome size in this case is probably due to variation of active/inactive condition of the nucleolar organizing region, or NOR, thus varied in size and influenced on the size of a short arm where probably NOR is located. Therefore, data on differential NOR staining or specific DNA marks should add to morphological details of Tachyoryctes karyotypes. AgNOR localization was first reported for two large pairs of subtelocentrics in the 3MA karyotype (Koka, by Baskevich et al., 1993) and doesn't specify something more for small chromosomes. The smallest chromosomal pair in all these cases is 


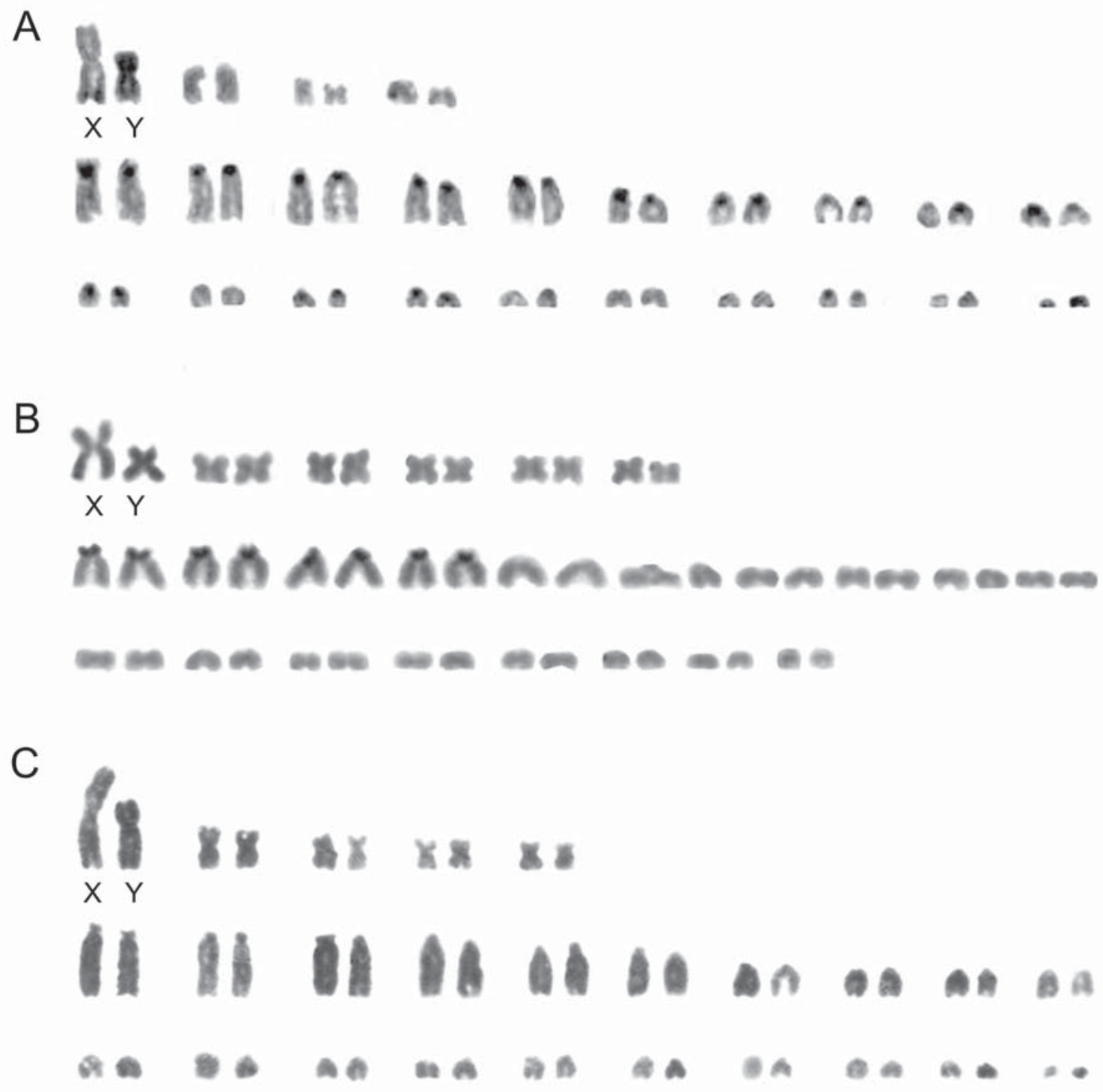

Figure 3. Karyograms of Ethiopian Tachyoryctes splendens differing in the number of small autosomal metacentrics (MA) and C-heterochromatin. A - Adami-Tulu, 3MA, autosomal C-blocks in a majority of acrocentric pairs; B - Debre-Sina, 5MA, C-positive short arms in 4 large subacrocentric pairs; C - Simien (Sankaber), 4MA, short arms in largest subacrocentrics are very likely heterochromatic. $\mathrm{X}$ and $\mathrm{Y}$ - the male sex chromosomes.

interpreted therefore as acrocentric for FN counts, before more detailed data become available.

\section{Discussion}

The results of our molecular genetic study indicate that the Ethiopian T. splendens s.l. is composed of at least three geographically separated and well-supported mitochondrial lineages (Southern, Northern and Eastern) that represent potential phylogenetic species. All three lineages are deeply divergent and separated from one another by uncorrected $c y t b$ distances $(\sim 11 \%)$ usually corresponding to species-level divergence in mam- mals (Bradley \& Baker, 2001). The Southern lineage possesses a unique karyotype $(2 \mathrm{n}=48,3 \mathrm{MA})$, while the chromosomal characteristics of the Eastern lineage remain unknown. Within the Northern lineage two distinct karyotypes were found: $2 \mathrm{n}=48,5 \mathrm{MA}$ and $2 \mathrm{n}=50$, 4MA. The latter chromosomal set was revealed only in specimens from the Simien Mountains, representing one of the northernmost localities of Tachyoryctes distribution range. The root-rats from this locality represent the most basal subclade of the Northern lineage and are separated from the remaining representatives of the lineage by an uncorrected $c y t b$ distance $(\sim 9 \%)$ generally considered to indicate cryptic taxonomic diversity (Baker \& Bradley, 2006). Therefore, the results of 
combined cytogenetic and molecular genetic analyses indicate that the Ethiopian T. splendens s.l. is a species complex containing at least four putative species, corresponding to independently evolved lineages: 1) Southern lineage, 2) Simien Mountains, 3) remaining subclades of Northern lineage, 4) Eastern lineage.

One critical remark on the use of the divergence criterion for defining species limits is that species, mainly those recent or incipient, are not necessarily exclusive in their gene pool due to retention of ancestral polymorphisms or introgression (Geurgas \& Rodrigues, 2010). As mitochondrial haplotypes are related by a strictly bifurcating genealogy due to their non-recombining and matrilineal mode of inheritance, deeply divergent mitochondrial lineages may be maintained in contiguous populations even in the absence of any reproductive barrier, resulting in a phylogeographic structure derived merely from the stochastic lineage sorting of ancestral polymorphisms. The population structure is boosted in species with limited vagility in fragmented habitats, in which populations can be partially isolated not only by distance alone but also by biotic and abiotic factors that can act as barriers to dispersal on a fine geographic scale (Irwin, 2002; Kuo \& Avise, 2005; Avise, 2009). In particular, subterranean rodents fit these criteria and represent a real challenge to species delimitation via molecular data. In general, they occupy fragmented habitats and present limited dispersal abilities in relation to the spatial scale of the habitat discontinuities (Steinberg \& Patton, 2000). Subterranean rodents occupy small population units with low genetic variation and high inter-population divergence (Lacey, 2000). Moreover, they exhibit in general the most spectacular chromosomal variability yet known in mammals (Reig et al., 1990). Most of their chromosomal diversity can be centered at both intraspecific (genera Thomomys Wied-Neuwied, 1839, Spalax Guldenstaedt, 1770 and Ellobius Fischer, 1814) and interspecific (genus Ctenomys Blainville, 1826) level (Bidau et al., 2003). Therefore, in the case of subterranean rodents (including Tachyoryctes), cytogenetic and mtDNA-based approaches might overestimate the number of potential species, and additional complementary data sources, such as sequencing of nuclear genes and multivariate analysis of cranial morphology (including type specimens) should be combined to help in species delimitation. Whether these mitochondrial and cytogenetic differentiations represent species boundaries remains to be investigated further, but what is clear from the results is that the diversity of the Ethiopian T. splendens has been underestimated. Although more data are needed prior to formal recognition of four lineages described above as taxonomic species, this study provides a framework for future studies in this complex.

All known fossil remains of the genus Tachyoryctes are restricted to Ethiopia. Three fossil species were described from the country: the Late Miocene T. makooka Wesselman, Black and Asnake, 2009, the Pliocene T. pliocaenicus Sabatier, 1978 and the Pleistocene T. konjiti Sabatier, 1982. The former species represents a link between Protachyoryctes tatroti Hinton, 1933 and Eicooryctes kaulialensis Flynn, 1982 from the Late Miocene of Pakistan and the derived African Tachyorictini (López-Antoñanzas \& Wesselman, 2013). Therefore, paleontological data suggest that the Ethiopian Plateau might be a primary center of diversification for modern representatives of the genus. The limited evidence available today supports this hypothesis. Thus, sole available non-Ethiopian Tachyoryctes from Kenya used in our phylogenetic analysis appears as a sister of the Southern lineage (Fig. 2). Furthermore, the sole described karyotype of non-Ethiopian Tachyoryctes, T. ruandae from East Congo (Matthey, 1967), is very similar to that of Ethiopian Southern lineage. Obviously, further study involving more samples (including $T$. macrocephalus and non-Ethiopian taxa) and based on the complex molecular, karyological and morphological investigation is required to clarify phylogenetic relationships among modern Tachyoryctes and analyse the taxonomic composition of the genus.

ACKNOWLEDGEMENTS. We are indebted to the Agricultural Bureau of Amhara Regional State (BahrDar) for permission to work in the Simien Mountains National Park and to the Oromia Agricultural Research Institute for permission to work at the Adami Tullu Agricultural Research Center. We are also indebted to the Ethiopian Wildlife Conservation Authority (EWCA) for permission to export Tachyoryctes specimens. We thank the warden and staff of the Simien Mountains National Park for the use of the Park buildings and equipment. We are grateful to Mrs. Vladimir Krylov, Alexander Miyasnikov and Zelalem Endale for their invaluable assistance during all stages of the expedition. We are especially indebted to our Project Coordinators Dr. Andrei Darkov (Joint Ethio-Russian Biological Expedition, Fourth Phase - JERBE-IV) and Ato Girma Yosef (Ethiopian Ministry of Science and Technology) for management of the expedition in the field and in Addis Ababa. The Department of Zoological Sciences, Addis Ababa University is highly acknowledged for providing overall support throughout the study process. At the final stage this work was supported by the Russian Foundation for Basic Research (Project 12-04-01283-a) and the Program of Basic Research of the Presidium of the Russian Academy of Sciences "Wildlife: Current Status and Problems of Development" (Subprogram "Dynamics and Conservation of Gene Pools").

\section{References}

Afework Bekele. 1986. The status of some mole-rats of the genus Tachyoryctes (Rodentia: Rhizomyidae) based upon craniometric studies // Revue de Zoologie Africaine. T.99. P.411-417.

Aniskin V.M., Lavrenchenko L.A., Varshavskii A.A. \& Milishnikov A.N. 1997. Karyotypes and chromosomal differentiation of two Tachyoryctes species (Rodentia, Ta- 
chyoryctinae) from Ethiopia // Russian Journal of Genetics. Vol.33. P.1079-1084.

Avise J.C. 2009. Phylogeography: retrospect and prospect // Journal of Biogeography. Vol.36. P.3-15.

Baker R.J. \& Bradley R.D. 2006. Speciation in mammals and the genetic species concept // Journal of Mammalogy. Vol.87. No.4. P.643-662.

Baskevich M.I., Orlov V.N., Afework Bekele \& Assefa Mebrate. 1993. Notes on the karyotype of Tachyoryctes splendens (Rüppel 1836) (Rodentia, Rhizomyidae) from Ethiopia // Tropical Zoology. Vol.6. P.81-88.

Beolchini F. \& Corti M. 2004. The taxonomy of the genus Tachyoryctes: a geometric morphometric approach // Italian Journal of Zoology. Vol.71. P.35-43.

Bidau C.J., Martí D.A. \& Giménez M.D. 2003. Two exceptional South American models for the study of chromosomal evolution: the tucura Dichroplus pratensis and the tucotucos of the genus Ctenomys // Historia Natural (Segunda Serie). Vol.II (8). P.53-72.

Bradley R.D. \& Baker R.J. 2001. A test of the genetic species concept: cytochrome $b$ sequences and mammals // Journal of Mammalogy. Vol.82. No.4. P.960-973.

Bulatova N.Sh. \& Lavrenchenko L.A. 2005. Possible karyological affinities of small mammals from north of the Ethiopian Plateau // Huber B.A., Sinclair B.J. \& Lampe K-H. (eds.). African Biodiversity: Molecules, Organisms, Ecosystems. New York: Springer Verlag. P.315319.

Calendini F. \& Martin J.F. 2005. PAUPUP version 1.0.3.1: a free graphical frontend for paup* DOS software. Available at: http://www.agromontpellier.fr/sppe/Recherche/ JFM/PaupUp

Fink S., Excoffier L. \& Heckel G. 2004. Mitochondrial gene diversity in the common vole Microtus arvalis shaped by historical divergence and local adaptations // Molecular Ecology. Vol.13. P.3501-3514.

Ford C.E. \& Hamerton J.L. 1956. A colchicine hypotonic citrate, squash sequence for mammalian chromosomes // Stain Technology. Vol.31. P.247-251.

Geurgas S.R. \& Rodrigues M.T. 2010. The hidden diversity of Coleodactylus amazonicus (Sphaerodactylinae, Gekkota) revealed by molecular data // Molecular Phylogenetics and Evolution. Vol.54. P.583-593.

Hasegawa M., Kishino H. \& Yano T. 1985. Dating of human-ape splitting by a molecular clock of mitochondrial DNA // Journal of Molecular Evolution. Vol.22. P.160 174.

Irwin D.E. 2002. Phylogeographic breaks without geographic barriers to gene flow // Evolution. Vol.56. P.23832394

Irwin D.M., Kocher T.D. \& Wilson A.C. 1991. Evolution of the cytochrome $b$ gene of mammals // Journal of Molecular Evolution. Vol.32. P.128-144.

Jaarola M., Martinkova N., Gündüz I., Brunhoff C., Zima J., Nadachowski A., Amori G., Bulatova N.S., Chondropoulos B., Fraguedakis-Tsolis S., González-Esteban J., José López-Fuster M., Kandaurov A.S., Kefelio lu H., da Luz Mathias M., Villate I. \& Searle J.B. 2004. Molecular phylogeny of the speciose vole genus Microtus (Arvicolinae, Rodentia) inferred from mitochondrial DNA sequences // Molecular Phylogenetics and Evolution. Vol. 33. P.647-663.

Jansa S.A., Goodman S.M. \& Tucker P.K. 1999. Molecular phylogeny and biogeography of the native rodents of
Madagascar (Muridae: Nesomyinae): a test of the singleorigin hypothesis // Cladistics. Vol.15. P.253-270.

Jarvis J.U.M. 2013. Genus Tachyoryctes Root-rats // Happold D.C.D. (ed.). Mammals of Africa. Vol.3. London: Bloomsbury Publishing. P.148-149.

Kumar S., Tamura K. \& Nei M. 2004. MEGA 3: Integrated software for molecular evolutionary genetics analysis and sequence alignment // Briefings in Bioinformatics. Vol.5. P.150-163.

Kuo C.-H. \& Avise J.C. 2005. Phylogeographic breaks in low-dispersal species: the emergence of concordance across gene trees // Genetica. Vol.124. P.179-186.

Lacey E.A. 2000. Spatial and social systems of subterranean rodents // Lacey E.A., Patton J.L. \& Cameron G.N. (eds.). Life Underground: The Biology of Subterranean Rodents. Chicago and London: University of Chicago Press. P.257-293.

López-Antoñanzas R. \& Wesselman H.B. 2013. Tachyoryctes makooka (Tachyoryctini, Spalacidae, Rodentia) and its bearing on the phylogeny of the Tachyoryctini // Palaeontology. Vol.56. P.157-166.

Mathew C.G. 1984. The isolation of high-molecular-weight eukaryotic DNA // Walker J.M. (ed.). Methods in Molecular Biology. New York: Humana. P.31-34.

Matthey R. 1967. Note sur la cytogénétique de quelques Muridés africains // Mammalia. Vol.31. P.281-287.

Musser G.G. \& Carleton M.D. 2005. Superfamily Muroidea // Wilson D.E. \& Reeder D.M. (eds.). Mammal Species of the World. A Taxonomic and Geographic Reference. Third Edition. Vol.2. Baltimore: Johns Hopkins University Press. P.894-1531.

Posada D. \& Crandall K.A. 1998. Modeltest: testing the model of DNA substitution // Bioinformatics. Vol.14. P.817-818.

Reig O.A., Busch C., Ortells M.O. \& Contreras J.L. 1990. An overview of evolution, systematics, population biology and molecular biology in Ctenomys // Nevo E. \& Reig O.A. (eds.). Evolution of Subterranean Mammals at the Organismal and Molecular Levels. New York: Allan Liss. P.71-96.

Sewnet Mengistu \& Afework Bekele. 2003. Geographic variations in the Ethiopian common mole-rat (Tachyoryctes splendens) based on morphometry // Ethiopian Journal of Biological Sciences. Vol.2. No.1. P.73-89.

Steinberg E.K. \& Patton J.L. 2000. Genetic Structure and the Geography of Speciation in Subterranean Rodents: Opportunities and Constraints for Evolutionary Diversification // Lacey E.A., Patton J.L. \& Cameron G.N. (eds.). Life Underground: The Biology of Subterranean Rodents. Chicago and London: University of Chicago Press. P.301-331.

Sumner A.T. 1972. A simple technique for demonstrating centromeric heterochromatin // Experimental Cell Research. Vol.75. P.304-306.

Swofford D.L. 2000. PAUP*: Phylogenetic analysis using parsimony (*and other methods). Version 4.0b2. Sunderland MA: Sinauer Associates.

Yalden D.W., Largen M.J. \& Kock D. 1976. Catalogue of the mammals of Ethiopia. 2. Insectivora and Rodentia // Monitore Zoologico Italiano (N.S.), Supplemento. Vol.8. No.1. P.1-118.

Zhou C., Zhou K. \& Zhang S. 2004. Molecular authentication of the animal crude drug Sailonggu (bone of Myospalax baileyi) // Biological and Pharmaceutical Bulletin. Vol.27. No.11. P.1850-1858. 